\title{
A survey of occupational cancer in the rubber and cablemaking industries: results of five- year analysis, 1967-71
}

\author{
A. J. FOX, D. C. LINDARS ${ }^{1}$, and R. OWEN \\ Employment Medical Advisory Service, Department of Employment, Chepstow Place, \\ London W2 4TF
}

Fox, A. J., Lindars, D. C., and Owen, R. (1974). British Journal of Industrial Medicine, 31, 140-151. A survey of occupational cancer in the rubber and cablemaking industries: results of five-year analysis, 1967-71. A mortality study of 40867 subjects employed in the rubber and cablemaking industries on 1 February 1967 is reported. No evidence is found of a continued excess risk of neoplasms of the bladder in people who entered the industry after 1949. For those employed before that date, during the period when known bladder carcinogens were in use, the SMR is higher than predicted, indicating that men are still dying with occupationally induced tumours.

An excess of all neoplasms was noted in the five years of the study. In certain sections of the industry (tyre manufacture, belting hose rubber with asbestos, and flooring industry) there is a particular excess of bronchial carcinoma. In those sections which use asbestos such an excess is not altogether surprising, but this does not apply to the tyre industry. The latter industry is sufficiently large (16 035 men in the study compared with 4350 in the belting, hose rubber with asbestos, and flooring industry) for attention to be focused on particular operations. Two job groups are found to share the excess: moulding, press, autoclave, and pan curemen; and finished goods, packaging, and despatch. Job selection may play a part in the latter, as the work is generally considered suitable for older and perhaps less healthy people.

Crude analyses have been undertaken to indicate whether the excesses are due to regional differences or to the population comprising an abnormally high proportion of smokers. No excesses are found in other smoking-related diseases. Although the effects of differences in smoking habit and regional differences cannot be ruled out, the indications are against these factors being the primary cause.

The difficulties of this type of study are discussed. It is emphasized that the results can be used only as an indication of a problem area and the type of further study required. A more exact study would concentrate on five-year cohorts of people who left the industry between 1940 and 1960. A study of five-year cohorts of people who entered the industry in the same period would also be valuable. An attempt has been made to perform the latter, but it would be hazardous to draw too many conclusions from this because the population comprises those who 'survive' in the industry until 1967.

Bladder cancer as an occupational hazard was first recognized by Rehn (1895). Reports of cases in the dyestuffs and chemical industries continued to

${ }^{1}$ Dr. Lindars died 22 August, 1973 appear, and in 1949 the Association of British Chemical Manufacturers sponsored an investigation into the problem. The report (Case, Hosker, McDonald, and Pearson, 1954) showed that an increase in bladder tumours was associated with 
exposure to benzidine, $\alpha$-naphthylamine, and $\beta$ naphthylamine. The carcinogenicity of $\beta$-naphthylamine had already been demonstrated (Hueper, Wiley, and Wolfe, 1938). In 1953 papilloma of the bladder occurring in certain occupations was prescribed for benefit under the Industrial Injuries Act, and in 1967 the Carcinogenic Substances Regulations brought these chemicals under strict control. Papilloma of the bladder is a term referring to primary neoplasm of the epithelium lining the urinary bladder. Such tumours may or may not be malignant from the earliest moment of detection.

During the investigation by Case et al. (1954) a study was made of records of the County Borough of Birmingham, selected because, although it was a large industrial city, it did not have a large dyestuff industry. A discovery was made that many cases of bladder tumour had arisen in workers at one large rubber works. Concurrently with this discovery it was noted that cases of bladder tumour had arisen in makers of rubber-compounding chemicals for use as anti-oxidants. These events were recorded by Case and Hosker (1954) and drew attention to tumours of the urinary bladder as an occupational disease in the rubber industry in England and Wales.

Meanwhile in 1949 the chemical manufacturers had already drawn the attention of rubber manufacturers to the presence of carcinogens in certain additives, and the use of these compounds was discontinued. All naphthylamines were withdrawn from that date, but benzidine continued in some sections of the industry up to 1956 (Parkes, 1964). The Rubber Manufacturers Employers' Association (now the British Rubber Manufacturers' Association) established a health unit in 1957 to provide cytodiagnostic facilities for exposed workers, and an explanatory booklet for workers was published ('Papilloma of the Bladder in the Rubber Industry 1961'), similar to one published nearly 10 years earlier by the Association of British Chemical Manufacturers.

Davies (1965) reported on the increased risk of bladder cancer in workers in electric-cable manufacture, in which rubber was used. A survey of the rubber and cablemaking industry was carried out by HM Factory Inspectorate in 1965. The objectives of the survey were twofold: to establish where certain defined substances containing carcinogens had been used, and to ensure that they were not currently in use; and, where they had been used, to arrange that both present and past employees possibly exposed to bladder carcinogens should receive advice to undergo a screening test (exfoliative cytology of the urine).

In the same year (1965) the Advisory Panel of the Senior Medical Inspector of Factories (now Chief Employment Medical Adviser) on occupational cancer gave approval for a mortality study of the rubber and cablemaking industries to compare the patterns of mortality in three exposure groups, namely:

(A) men employed in factories which used known carcinogenic compounds and men who entered those factories before 1 January 1950;

(B) men employed in factories which used known carcinogenic compounds and who entered those factories after 31 December 1949 ; and

(C) men employed in factories which had never used known carcinogenic compounds.

The results of a first analysis of this study are reported in this paper.

\section{Method}

On 1 February 1967, a census was taken of all men aged between 35 and 65 years employed in the rubber and cablemaking industries. In Great Britain 381 firms were identified by the Inspectorate and all co-operated in the census (HM Chief Inspector of Factories, 1968). Census

TABLE 1

CODES FOR LABELLING INDUSTRIES AND JOBS

\begin{tabular}{|c|c|}
\hline $\begin{array}{l}\text { Industry } \\
\text { code }\end{array}$ & Type of industry \\
\hline 1 & Tyres \\
\hline 2 & Tyre remoulds and retreads \\
\hline 3 & Cables and electrical goods \\
\hline 4 & $\begin{array}{l}\text { Adhesives, rubber solutions, and sealing } \\
\text { compounds }\end{array}$ \\
\hline 5 & $\begin{array}{l}\text { Clothing, rubberized textiles, rubberized hair } \\
\text { and carpeting }\end{array}$ \\
\hline 6 & Belting, hose rubber with asbestos, flooring \\
\hline 7 & $\begin{array}{l}\text { Footwear and footwear supplies except } \\
\text { adhesives }\end{array}$ \\
\hline 8 & Printing supplies \\
\hline 9 & Surgical and medical goods and gloves \\
\hline 10 & Ebonite and Vulcanite \\
\hline 11 & $\begin{array}{l}\text { Sponge rubber, rubber with plastic, crêpe } \\
\text { rubber, etc. }\end{array}$ \\
\hline $\begin{array}{l}12 \\
13\end{array}$ & $\begin{array}{l}\text { Other rubber (brushes, sports goods and toys) } \\
\text { Mouldings, motor accessories and mechanicals }\end{array}$ \\
\hline Job code & Type of job \\
\hline $\begin{array}{l}1 \\
2\end{array}$ & $\begin{array}{l}\text { Crude material storeman } \\
\text { Compounding, weighing, reforming, } \\
\text { washing, etc. }\end{array}$ \\
\hline 3 & Latex mixing, frothing, dipping \\
\hline 4 & Extruding, calendering, spreading, etc. \\
\hline 5 & $\begin{array}{l}\text { Component building, preparation, assembly, } \\
\text { etc. }\end{array}$ \\
\hline 6 & Moulding, press, autoclave, pan cureman \\
\hline 7 & Inspection, painting \\
\hline 8 & Finished goods, stores, packaging despatch \\
\hline 9 & Site workers, general truck drivers, etc. \\
\hline 10 & Engineering and building maintenance \\
\hline 11 & Canteens \\
\hline 12 & Factory operating staff \\
\hline 13 & Commercial staff \\
\hline 14 & Engineering staff \\
\hline 15 & Technical staff \\
\hline
\end{tabular}


cards were completed for 49068 subjects; 7087 cards were rejected for various reasons, e.g., they did not fall into the correct age range; they were female; they were not of UK origin, or because they had not worked for one year in the industry. Details of the remaining 41981 persons considered suitable for the study were sent to the National Health Service central registers in England and Wales, and in Scotland. Of these, 40867 (97.35\%) were traced to form the population for the study of mortality and, eventually, cancer registration. A summary of a preliminary analysis was reported by Lloyd Davies (1971).

In the following analysis deaths in the three groups defined above are contrasted. It has also been possible to make a comparison between different sections of the industries, and between occupations (industrial groups and job groups, Table 1). Statistical comparisons are made between observed and expected deaths. The expected deaths are, in the main, calculated using the England and Wales sex-age-standardized death rates published annually by the Registrar General (1967-70). The 1971 death rates are preliminary estimates provided by the Registrar General in personal communication. In several tables non-age-standardized death rates have been used in order to focus attention on particular subgroups. Significant findings have subsequently been confirmed or disproved using age-standardized death rates. In this way we limit the number of statistical tests performed and reduce the likelihood of finding significant results due to chance. A comparison between observed and expected values is made by assuming a Poisson distribution with the mean equal to the expected values. Pearson and Hartley (1962) give the probabilities of individual terms of the Poisson distribution. For a mean greater than 15.0 the normal approximation to the Poisson distribution has been assumed. An attempt is made to investigate the possible role of smoking habits by comparing the standardized mortality ratios (SMR) for carcinoma of the bronchus with those for other smoking-related diseases. Differences with a likelihood of less than 0.05 being due to chance are considered to be statistically significant. Many of the findings attain higher significance and the probabilities are given.

Causes of death are classified according to the International Classification of Diseases (1967). In the initial analysis (Table 2) cancers of certain specific sites were included as these were thought possibly to be associated with occupation.

\section{Healthy population}

The population studied comprises people who were in employment as at 1 February 1967. The national population, with whom comparisons are made, includes people who are sick and unable to work. The effect on the comparison is such that in the first year of the study a low SMR is observed (Table 2). So that this does not affect our findings the deaths in 1967 are not included when statistical comparisons are being made. The observed and expected deaths for 1967 are, however, given in Table 2.

\section{Results}

An important finding in the overall deaths (observed, expected, and SMR) for the main causes of interest (Table 2) is that there is a significant excess of all neoplasms $(\mathrm{P}<0.001)$.

\section{Carcinoma of bladder (ICD 188.0-188.9)}

From Table 2 it can be seen that in the last four years of the study 23 deaths from bladder tumours have been observed as compared with 20 expected deaths. Table 3 categorizes these deaths according to exposure group. Although the numbers are small, the excess of deaths due to carcinoma of the bladder are occurring primarily in those subjects who were

TABLE 2

Observed and Expected Deaths for Cause Groups of Interest Given for Each Year of Survey (Because of the effect of selecting a working population 1967 is excluded from comparisons.)

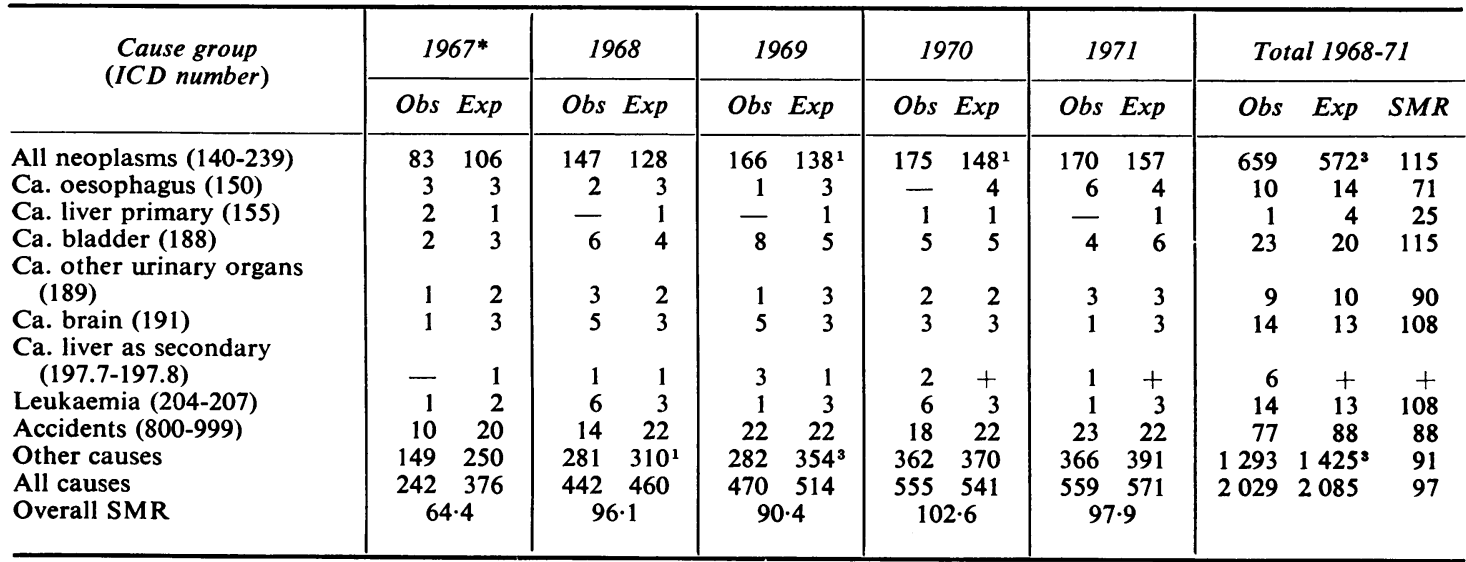

*Only 11 months from 1 February

+ Expected values not calculated

${ }^{1} \mathbf{P}<0.05 ; \quad{ }^{2} \mathbf{P}<0.01 ;{ }^{3} \mathbf{P}<0.001$ 
TABLE 3

ObSERVEd ANd EXPECTED Deaths for NeOPLASM OF BLADDER (ICD 188.0-188.9) SUBCATEGORIZED ACCORDING TO EXPOSURE GROUP

\begin{tabular}{c|rcc|c}
\hline \multirow{2}{*}{$\begin{array}{c}\text { Exposure } \\
\text { group }\end{array}$} & \multicolumn{3}{|c|}{ Deaths 1968-71 } & \\
\cline { 2 - 4 } & Obs. & Exp. & SMR & \\
\hline A & 11 & $8 \cdot 5$ & 130 & NS \\
B & 7 & 7.2 & 97 & NS \\
C & 5 & 4.4 & 114 & NS \\
\hline Total & 23 & 20.0 & 115 & NS \\
\hline
\end{tabular}

exposed to known bladder carcinogens before 1950 . The excess observed here is smaller than that found previously (Case and Hosker, 1954). It should be remembered, however, that since our population was still in the industry on 1 February 1967 their last exposure was at least 17 to 22 years before death and their first exposure might have been considerably earlier. Veys (1969) observed an average latent period of 17.6 years from first exposure; in the chemical industry Case et al. (1954) found a latent period of $\mathbf{1 7 . 8}$ years with a standard deviation of $7 \cdot 18$ years. Both these estimates are based on 'censored data' 1 in that some people had not yet developed tumours when the estimates were made. It is, therefore, quite likely that the SMR for group A will converge to that for the other exposure groups because the effect of the excess of tumours caused by exposure to known carcinogens will be diminishing. The SMRs for exposure groups B and C provide no evidence that there is still an excess risk of bladder tumours in the industry. Although this is not conclusive evidence that there is no risk, it would suggest that any excess is small relative to that previously observed.

${ }^{1}$ The data are right-censored in the statistical sense (see, for example, Peto (1973))
All neoplasms (ICD 140.0-239.9)

Table 4 gives the number and percentage of people included in each of the exposure groups and the number of observed and expected deaths due to all neoplasms (ICD 140.0-239.9). As can be seen from the table, the significant excess of cancer deaths is observed primarily in those falling into exposure group B. This difference might be explained partially by the later analysis of deaths according to the years in which subjects entered the industry.

\section{Analysis of different sections of the industry}

Observed deaths (1968-71) are given in Table 5 for carcinoma of the bronchus, carcinoma of the bladder, other neoplasms, and all other causes of death. These have been broken down according to industrial group (Table 1) and crude expected values have been calculated to indicate the sectors of the industry meriting further study.

The expected values in Table 5 are obtained by multiplying the expected values for each cause of death in the total rubber and cablemaking industry by the proportion of the initial population who were in the particular sector of the industry. An example is given below the table. This method of calculation is obviously crude because it takes no account of differences in age structures between sectors of the industry. As will be seen from Table 6, the assumption proves reasonably valid for industrial group 1 (tyres).

Industrial group 1 (tyres) From Table 5 it is clear that further study of industrial group 1 is required. In Table 6 accurate expected values are calculated on the basis of 'man years of risk'. From this Table it becomes evident that in industrial group 1 there is a significant excess of all neoplasms (273 observed as compared with 217.4 expected, $P<0.001)$ and of carcinoma of the bronchus (131 observed as compared with 97.8 expected, $P<0.001$ ). Expected values for ischaemic heart disease, chronic bronchitis

TABLE 4

Observed and Expected Deaths and Standardized Mortality Ratio for Deaths due to all NeOPlasms (ICD 140.0-239.9) SUbCaTegorized aCCORDING to EXPOSURE Group

\begin{tabular}{c|c|ccc|c}
\hline \multirow{2}{*}{$\begin{array}{c}\text { Exposure } \\
\text { group }\end{array}$} & $\begin{array}{c}\text { Number } \\
(\%)\end{array}$ & Obs. & Deuths 1968-71 & \\
\cline { 2 - 6 } A & $\begin{array}{r}12781 \\
(31.3 \%)\end{array}$ & 237 & 233 & SMR & NS \\
B & $\begin{array}{r}18116 \\
(44.3 \%) \\
9970\end{array}$ & 274 & 212 & 102 & P \\
C & $(24.4 \%)$ & 148 & 126 & 117 & NS \\
\hline Total & 40867 & 659 & 572 & 115 & P $<0.001$ \\
\hline
\end{tabular}


TABLE 5

A Crude Guide to Sectors of Industry meriting Further Study including All Deaths Observed 1968-71

\begin{tabular}{|c|c|c|c|c|c|c|c|c|c|c|c|c|c|}
\hline \multirow{2}{*}{$\begin{array}{c}\text { Industrial } \\
\text { group }\end{array}$} & \multicolumn{2}{|c|}{$\begin{array}{l}\text { Carcinoma } \\
\text { of bronchus }\end{array}$} & \multicolumn{2}{|c|}{$\begin{array}{l}\text { Neoplasm } \\
\text { of bladder }\end{array}$} & \multicolumn{2}{|c|}{$\begin{array}{c}\text { Other } \\
\text { neoplasm s }\end{array}$} & \multicolumn{2}{|c|}{$\begin{array}{c}\text { All } \\
\text { neoplasms }\end{array}$} & \multicolumn{2}{|c|}{$\begin{array}{l}\text { All other } \\
\text { causes }\end{array}$} & \multicolumn{2}{|c|}{$\begin{array}{l}\text { All causes } \\
\text { of death }\end{array}$} & \multirow{2}{*}{$\begin{array}{c}\text { Total } \\
\text { population } \\
\text { l Feb. ' } 67\end{array}$} \\
\hline & Obs. & Exp.* & Obs. & $x p . *$ & Obs. & Exp.* & Obs. & Exp.* & Obs. & Exp.* & Obs. & Exp.* & \\
\hline $\begin{array}{r}1 \\
2 \\
3 \\
4 \\
5 \\
6 \\
7 \\
8 \\
9 \\
10 \\
11 \\
12 \\
13\end{array}$ & $\begin{array}{r}131 \\
7 \\
13 \\
5 \\
14 \\
44 \\
14 \\
4 \\
5 \\
5 \\
6 \\
4 \\
49\end{array}$ & $\begin{array}{c}100^{2} \\
6 \\
16 \\
5 \\
11 \\
27^{2} \\
19 \\
2 \\
4 \\
3 \\
8 \\
3 \\
52\end{array}$ & $\begin{array}{l}7 \\
3 \\
- \\
2 \\
- \\
2 \\
1 \\
1 \\
5\end{array}$ & $\begin{array}{l}\frac{8}{1} \\
1 \\
2 \\
-1 \\
- \\
1 \\
4\end{array}$ & $\begin{array}{r}135 \\
8 \\
19 \\
3 \\
19 \\
41 \\
27 \\
6 \\
7 \\
4 \\
9 \\
3 \\
54\end{array}$ & $\begin{array}{r}116 \\
7 \\
18 \\
6 \\
13 \\
32 \\
21 \\
21 \\
5 \\
4 \\
9 \\
3 \\
60\end{array}$ & $\begin{array}{r}273 \\
15 \\
35 \\
8 \\
33 \\
87 \\
43 \\
10 \\
14 \\
9 \\
16 \\
8 \\
108\end{array}$ & $\begin{array}{c}224^{2} \\
13 \\
35 \\
11 \\
25 \\
61^{3} \\
41 \\
4 \\
9 \\
7 \\
18 \\
6 \\
116\end{array}$ & $\begin{array}{r}510 \\
27 \\
90 \\
30 \\
66 \\
177 \\
98 \\
8 \\
29 \\
12 \\
46 \\
14 \\
263\end{array}$ & $\begin{array}{c}594^{3} \\
34 \\
92 \\
29 \\
67 \\
161 \\
110 \\
12 \\
25 \\
18 \\
46 \\
16 \\
309^{2}\end{array}$ & $\begin{array}{r}783 \\
42 \\
125 \\
38 \\
99 \\
264 \\
141 \\
18 \\
43 \\
21 \\
62 \\
22 \\
371\end{array}$ & $\begin{array}{r}818 \\
47 \\
128 \\
40 \\
92 \\
222^{2} \\
151 \\
16 \\
34 \\
25 \\
64 \\
22 \\
426^{2}\end{array}$ & $\begin{array}{r}16035 \\
912 \\
2506 \\
777 \\
1811 \\
4350 \\
2958 \\
315 \\
671 \\
499 \\
1255 \\
438 \\
8340\end{array}$ \\
\hline Total & 301 & 256 & 23 & 20 & 335 & 296 & 659 & 572 & 1370 & 1514 & 2029 & 2086 & 40867 \\
\hline
\end{tabular}

*Expected deaths based on the proportion of people in particular industrial groups multiplied by the total number of deaths expected for cause of interest, e.g., carcinoma of bronchus, group 1: Expected $=256 \times \frac{16035}{40867}=100.4$

${ }^{1} \mathbf{P}<0.05 ; \quad{ }^{2} \mathrm{P}<0.01 ;{ }^{3} \mathrm{P}<0.001$

and other respiratory diseases have been calculated from 1970 age-standardized national rates; otherwise annual rates have been used.

In Table 7 the observed and expected deaths due to carcinoma of the bronchus are calculated for each age group in exposure groups $\mathbf{A}$ and $\mathbf{B}$. Figures for exposure group $\mathrm{C}$ are not given because of the limited number of 'man years at risk'. These can, however, be obtained by subtraction from the total tyre sector. The outstanding feature in this Table is a significant excess in exposure group $B$ and particularly in age group 55-64 (observed 40 as com- pared with an expected 21.13, $P<0.001$ ). There is a slight but not statistically significant excess in groups $\mathbf{A}$ and $\mathbf{C}$.

Industrial group 6 (belting, hose rubber with asbestos, flooring) In Table 5 the relatively crude calculation of expected values suggests that industrial group 6 (belting, hose rubber with asbestos, and flooring) merits further study. The estimated excess incidence of carcinoma of the bronchus and of causes of death other than neoplasm is confirmed by the more accurate calculation of age-standardized expected

TABLE 6

Observed and Age-Standardized Nationally Expected Deaths in Tyre Sector of Rubber and CABLEMAKING INDUSTRIES 1968-71

\begin{tabular}{|c|c|c|c|c|c|c|c|c|}
\hline & $\begin{array}{c}\text { All } \\
\text { neoplasms } \\
\\
(I C D \\
140-239)\end{array}$ & $\begin{array}{c}\begin{array}{c}\text { Carcinoma } \\
\text { of bronchus }\end{array} \\
(I C D \\
162 \cdot 1)\end{array}$ & $\begin{array}{c}\text { Carcinoma } \\
\text { of bladder } \\
\\
(I C D \\
188)\end{array}$ & $\begin{array}{c}\text { Bronchitis } \\
\text { and } \\
\text { emphysema } \\
(I C D \\
\left.490-492^{*}\right)\end{array}$ & $\begin{array}{c}\text { Other } \\
\text { respiratory } \\
\text { Disease } \\
\text { (ICD } \\
460-519^{*} \\
\text { not } \\
490-492)\end{array}$ & $\begin{array}{c}\text { Ischaemic } \\
\text { heart } \\
\text { disease } \\
(I C D \\
\left.410-414^{*}\right)\end{array}$ & $\begin{array}{c}\text { All } \\
\text { other } \\
\text { causes }\end{array}$ & $\begin{array}{c}\text { All } \\
\text { causes } \\
\text { of death }\end{array}$ \\
\hline $\begin{array}{l}\text { Observed } \\
\text { Expected } \\
\text { SMR }\end{array}$ & $\begin{array}{l}273 \\
217 \cdot 4 \\
126^{3}\end{array}$ & $\begin{array}{c}131 \\
97 \cdot 8 \\
134^{3}\end{array}$ & $\begin{array}{l}7 \\
7 \cdot 5 \\
93\end{array}$ & $\begin{array}{l}43 \\
52 \cdot 3 \\
8 \cdot 2\end{array}$ & $\begin{array}{l}24 \\
43 \cdot 8 \\
55\end{array}$ & $\begin{array}{l}246 \\
264 \cdot 2 \\
93\end{array}$ & $\begin{array}{l}197 \\
195 \cdot 0 \\
101\end{array}$ & $\begin{array}{l}783 \\
786.4 \\
99.6\end{array}$ \\
\hline
\end{tabular}

*Expected deaths based on 1970 rates

†Expected deaths calculated by subtraction

${ }^{3} \mathbf{P}<0.001$ 
TABLE 7

Deaths due to Carcinoma of Bronchus, Observed 1968-71 in Tyre Industry Related TO AGE AND EXPOSURE GROUP

\begin{tabular}{|c|c|c|c|c|c|c|}
\hline \multirow{3}{*}{ Age group } & \multicolumn{4}{|c|}{ Exposure group } & \multirow{2}{*}{\multicolumn{2}{|c|}{ Total tyre sector }} \\
\hline & \multicolumn{2}{|c|}{$A$} & \multicolumn{2}{|c|}{$B$} & & \\
\hline & Obs. & $S M R$ & Obs. & $S M R$ & Obs. & $S M R$ \\
\hline $\begin{array}{l}35-44 \\
45-54 \\
55-64 \\
65-70\end{array}$ & $\begin{array}{r}1 \\
11 \\
34 \\
19\end{array}$ & $\begin{array}{r}196 \\
135 \\
98 \\
132\end{array}$ & $\begin{array}{r}2 \\
13 \\
40 \\
9\end{array}$ & $\begin{array}{l}108 \\
131 \\
189^{3} \\
163\end{array}$ & $\begin{array}{r}4 \\
24 \\
75 \\
28\end{array}$ & $\begin{array}{l}160 \\
129 \\
132^{1} \\
140\end{array}$ \\
\hline Total & 65 & 112 & 64 & $167^{3}$ & 131 & $134^{3}$ \\
\hline
\end{tabular}

${ }^{1} \mathrm{P}<0.05 ; \quad{ }^{3} \mathrm{P}<0.001$

values based on national rates as given in Table 8 . Since this group comes into contact with asbestos, as well as other chemicals, these results are not altogether surprising. Clearly, further study of this group would be required, in particular to discover the levels of asbestos to which people in this industry are exposed.

Industrial group 8 An excess incidence in industrial group 8 (printing supplies) of neoplasms, other than those of the bronchus and bladder, is suggested in Table 5. This excess is, however, not confirmed by national age-standardized comparisons. As the number of people in this group is small it would in any case be difficult to draw conclusions.

Possible influence of smoking habit and/or urban effects

When studying a population with an excess incidence of bronchial carcinomas two possible explanations immediately spring to mind. The first is related to the smoking habits of the population (Royal College of Physicians, 1971) and the second is related to the effect of the area in which the factories are situated (Howe, 1963; Registrar General, 1967). Both these factors are extremely difficult to rule out as causes unless detailed histories have been recorded. No record of the distribution of smoking habits was made in the population under study.

One method of estimating the role played by smoking habit and by urban effect is to consider the relative incidence of other smoking and urbanrelated diseases, such as chronic bronchitis and emphysema (ICD 490-492), other respiratory disease (ICD 460-519 excluding 490-492), ischaemic heart disease (ICD 410-414), and other neoplasms (ICD 140-239 excluding 162.1). In Table 9 the observed deaths in the tyre industry are compared with those for the remainder of the rubber and cablemaking industry for these cause groups. In an attempt to account for urban effects comparison is made with 1970 age-standardized death rates for Merseyside, an area with one of the largest urban effects in the United Kingdom. When studying this Table one should remember that we have shown an overall excess of neoplasms in the whole rubber and cablemaking industry and particularly an excess of bronchial carcinoma. Table 9 shows that although

TABLE 8

Mortality Pattern in Belting, Hose Rubber with Asbestos, Flooring (1968-71) according to Age GROUP

\begin{tabular}{|c|c|c|c|c|c|c|c|c|c|c|c|c|}
\hline \multirow{2}{*}{$\begin{array}{c}\text { Age } \\
\text { group }\end{array}$} & \multicolumn{3}{|c|}{ Carcinoma of bronchus } & \multicolumn{3}{|c|}{ All other neoplasms } & \multicolumn{3}{|c|}{ Other causes of death } & \multicolumn{3}{|c|}{ All causes of death } \\
\hline & Obs. & Exp. & $S M R$ & Obs. & Exp. & $S M R$ & Obs. & Exp. & $S M R$ & Obs. & Exp. & $S M R$ \\
\hline $\begin{array}{l}35-44 \\
45-54 \\
55-64 \\
65-74\end{array}$ & $\begin{array}{c}2 \\
5 \\
22^{1} \\
13^{2}\end{array}$ & $\begin{array}{r}0.74 \\
4.95 \\
14.43 \\
5.57\end{array}$ & $\begin{array}{l}270 \\
101 \\
152 \\
233\end{array}$ & $\begin{array}{r}6 \\
8 \\
19 \\
10\end{array}$ & $\begin{array}{r}1 \cdot 87 \\
6 \cdot 79 \\
15 \cdot 13 \\
6 \cdot 99\end{array}$ & $\begin{array}{l}321 \\
118 \\
126 \\
143\end{array}$ & $\begin{array}{l}14 \\
41 \\
84 \\
40\end{array}$ & $\begin{array}{r}8 \cdot 78 \\
32 \cdot 23 \\
75 \cdot 40 \\
37 \cdot 16\end{array}$ & $\begin{array}{l}159 \\
127 \\
111 \\
108\end{array}$ & $\begin{array}{r}22^{2} \\
54 \\
125 \\
63\end{array}$ & $\begin{array}{r}11 \cdot 39 \\
43 \cdot 97 \\
104 \cdot 96 \\
49 \cdot 72\end{array}$ & $\begin{array}{l}193 \\
123 \\
119 \\
127\end{array}$ \\
\hline Total & $42^{3}$ & $25 \cdot 67$ & 164 & $43^{1}$ & $30 \cdot 39$ & 140 & 179 & $153 \cdot 58$ & 117 & $264^{3}$ & 210.04 & 126 \\
\hline
\end{tabular}

$P<0.05 ;{ }^{2} P<0.01 ;{ }^{3} P<0.001$ 
TABLE 9

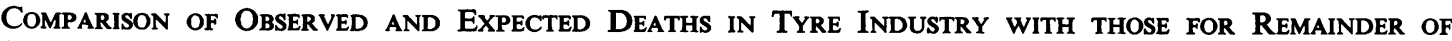
RUBBER AND CABLEMAKING INDUSTRY (Expected deaths based on 1970 age-standardized rates for Merseyside conurbation)

\begin{tabular}{|c|c|c|c|c|c|c|c|c|c|c|c|c|}
\hline & Obs. & Exp. & $S M R$ & Obs. & Exp. & $S M R$ & Obs. & Exp. & $S M R$ & Obs. & Exp. & $S M S$ \\
\hline $\begin{array}{l}\text { emphysema } \\
\text { All other respiratory }\end{array}$ & 43 & $78 \cdot 6$ & $54 \cdot 7$ & 3 & $6 \cdot 5$ & $46 \cdot 2$ & 77 & $129 \cdot 6$ & $59 \cdot 2$ & 120 & $208 \cdot 2$ & \\
\hline $\begin{array}{l}\text { disease } \\
\text { Ischaemic heart disease } \\
\text { All other causes } \\
\text { All causes of death }\end{array}$ & $\begin{array}{r}24 \\
246 \\
197 \\
783\end{array}$ & $\begin{array}{r}6 \hat{2} \cdot 7 \\
302 \cdot 7 \\
229 \cdot 9 \\
958 \cdot 2\end{array}$ & $\begin{array}{l}38 \cdot 3 \\
81 \cdot 3 \\
85 \cdot 7 \\
81 \cdot 7\end{array}$ & $\begin{array}{r}3 \\
16 \\
9 \\
60\end{array}$ & $\begin{array}{r}5 \cdot 2 \\
25 \cdot 8 \\
19 \cdot 6 \\
81 \cdot 3\end{array}$ & $\begin{array}{l}57 \cdot 7 \\
62 \cdot 0 \\
45 \cdot 9 \\
73 \cdot 8\end{array}$ & $\begin{array}{r}46 \\
420 \\
317 \\
1246\end{array}$ & $\begin{array}{r}103 \cdot 1 \\
486 \cdot 8 \\
373 \cdot 3 \\
1551 \cdot 5\end{array}$ & $\begin{array}{l}44 \cdot 6 \\
86 \cdot 3 \\
84 \cdot 9 \\
80 \cdot 3\end{array}$ & $\begin{array}{r}70 \\
666 \\
514 \\
2029\end{array}$ & $\begin{array}{r}165 \cdot 8 \\
789 \cdot 5 \\
603 \cdot 2 \\
2509 \cdot 7\end{array}$ & $\begin{array}{l}42 \cdot 2 \\
84 \cdot \overline{1} \\
85 \cdot 2 \\
80.8\end{array}$ \\
\hline
\end{tabular}

the SMR for carcinoma of the bronchus in the tyre sector is higher (approximately $24 \%$ higher) than that for the remainder of the rubber and cablemaking industry, the SMR for other smoking and urban-related disease is approximately the same. In particular, bronchitis and emphysema, whose rates are usually highly correlated with those for bronchial carcinoma, is estimated at approximately $8 \%$ lower for the tyre sector as compared with the remainder of the industry. This would suggest that neither the urban effect nor a smoking effect is likely to be the primary cause of our observed excess. This point is magnified if one looks at job 6 , in the tyre sector (moulding, press, autoclave, and pan cureman), which is also given in Table 9. The SMR for carcinoma of the bronchus is estimated to be approximately $65 \%$ higher than in the industry excluding the tyre sector whereas for bronchitis and emphysema it is estimated to be approximately $22 \%$ lower. It should be noted that smoking habit and urban effect are not so easily ruled out in industries 6 and 8. This is because, as is shown in Table 8 for industry 6, the SMRs for most diseases in these groups are raised. We have, however, already emphasized that these industries should be studied in greater depth.

\section{Guide to jobs affected}

When the population was set up in 1967 details of job as at 1 February 1967 were recorded and categorized as shown in Table 1 . The difficulties of drawing conclusions from this classification ought

\section{TABLE 10}

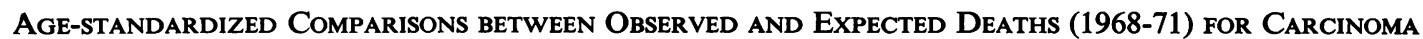
of Bronchus, Other Neoplasms and Other Causes of Death in Moulding, Press, Autoclave and Pan CuReman in the Tyre Sector

\begin{tabular}{|c|c|c|c|c|c|c|c|c|c|c|c|c|}
\hline \multirow{2}{*}{$\begin{array}{l}\text { Age at } \\
\text { death }\end{array}$} & \multicolumn{3}{|c|}{ Carcinoma of bronchus } & \multicolumn{3}{|c|}{ Other neoplasms } & \multicolumn{3}{|c|}{ Other causes of death } & \multicolumn{3}{|c|}{ All causes of death } \\
\hline & Obs. & Exp. & $S M R$ & Obs. & Exp. & $S M R$ & Obs. & Exp. & $S M R$ & Obs. & Exp. & $S M R$ \\
\hline $\begin{array}{l}35-44 \\
45-54 \\
55-64 \\
65-70\end{array}$ & $\begin{array}{l}- \\
4 \\
8 \\
3\end{array}$ & $\begin{array}{l}0.25 \\
1.75 \\
5.05 \\
1.33\end{array}$ & $\begin{array}{l}-\overline{286} \\
158 \\
226\end{array}$ & $\begin{array}{r}2 \\
5 \\
7 \\
-\end{array}$ & $\begin{array}{l}0.66 \\
2 \cdot 37 \\
5.64 \\
1 \cdot 58\end{array}$ & $\begin{array}{c}303 \\
211 \\
124 \\
-\end{array}$ & $\begin{array}{r}- \\
3 \\
26 \\
2\end{array}$ & $\begin{array}{r}3.08 \\
12.24 \\
25.99 \\
7.09\end{array}$ & $\begin{array}{r}25 \\
100 \\
28\end{array}$ & $\begin{array}{r}2 \\
12 \\
41 \\
5\end{array}$ & $\begin{array}{r}3.99 \\
16.36 \\
36.68 \\
10.00\end{array}$ & $\begin{array}{r}50 \\
73 \\
112 \\
50\end{array}$ \\
\hline Total & $15^{1}$ & $8 \cdot 37$ & 179 & 14 & $10 \cdot 25$ & 137 & 31 & $48 \cdot 40$ & 64 & 60 & $67 \cdot 02$ & 90 \\
\hline
\end{tabular}

${ }_{P}<0.05$

Note: For 'other causes of death' in the 45-54 and 65-70 age groups there are significant deficiencies of deaths. 
TABLE 11

Age-Standardized Comparisons between Observed and Expected Deaths (1968-71) for Carcinoma of Bronchus, Other Neoplasms and Other Causes of Death in Finished Goods, Stores and Packaging Despatch Men in the TyRe Sector

\begin{tabular}{|c|c|c|c|c|c|c|c|c|c|c|c|c|}
\hline \multirow{2}{*}{$\begin{array}{l}\text { Age at } \\
\text { death }\end{array}$} & \multicolumn{3}{|c|}{ Carcinoma of bronchus } & \multicolumn{3}{|c|}{ Other neoplasms } & \multicolumn{3}{|c|}{ Other causes of death } & \multicolumn{3}{|c|}{ All causes of death } \\
\hline & Obs. & Exp. & $S M R$ & Obs. & Exp. & $S M R$ & Obs. & Exp. & $S M R$ & Obs. & Exp. & $S M R$ \\
\hline $35-44$ & - & 0.11 & - & 1 & 0.29 & 344 & 2 & 1.44 & 139 & 3 & 1.84 & 163 \\
\hline $45-54$ & 2 & 0.96 & 208 & 3 & $1 \cdot 30$ & 231 & 10 & $6 \cdot 27$ & 159 & $15^{1}$ & 8.53 & 176 \\
\hline $55-64$ & $10^{1}$ & $4 \cdot 19$ & 239 & 4 & 4.68 & 85 & 18 & $21 \cdot 65$ & 83 & 33 & 30.52 & 108 \\
\hline $65-70$ & 1 & 1.49 & 67 & 2 & 1.77 & 113 & 8 & 9.08 & 88 & 11 & 12.34 & 89 \\
\hline Total & $13^{1}$ & 6.75 & 193 & 10 & 8.04 & 124 & 39 & 38.44 & 101 & 62 & 53.24 & 116 \\
\hline
\end{tabular}

${ }^{1} \mathbf{P}<0.05$

to be emphasized at this stage. Since the jobs are defined as at 1 February 1967 , it is likely that some of the people who were in a particular job in, say, 1950 were in other jobs in 1967. It is also probable that a large proportion would have left the industry before 1967, but this factor is dealt with later in the discussion. The effect of job rotation is such that, if there is an increased risk attached to a particular job, this risk will not be as overt as it might be if a proper cohort study had been undertaken. Also if there is a tendency for older and perhaps less healthy people to be given a particular job, this job will appear to have a high risk attached to it. These factors must be borne in mind when studying the industry with a view to detecting the jobs in which most risk is incurred. The tyre sector has been screened crudely as the total industry was screened (Table 5). This crude analysis indicates that two job groups merit much closer attention. These are job
6 (moulding, press, autoclave, and pan cureman) and job 8 (finished goods; stores, packaging, despatch). The results of detailed age-standardized comparisons for these two groups are given in Tables 10 and 11. Although there are marginally significant excesses $(P<0.05)$, the numbers here are extremely small. The proportion of bronchial carcinomas are, however, extremely high $(25 \%$ and $21 \%$ of all deaths in jobs 6 and 8 respectively). It should be pointed out with respect to job 8 that by its nature this job attracts older and also perhaps less healthy people. This factor may play an important role in the causation of the excess in this group. Clearly, as well as studying the whole tyre industry particular attention should be paid to these jobs.

Year of entry into the industry

In Table 12 the mortality pattern in industry 1 is compared with that for the remainder of the rubber

TABLE 12

COMPARISON OF MORTALITY WITH YeAR OF ENTRY INTO INDUSTRY

(Figures in parentheses are the proportion of population who died 1968-71 and proportions of deaths from bronchial carcinoma and from other neoplasms.)

\begin{tabular}{|c|c|c|c|c|c|c|c|c|c|c|c|c|c|c|}
\hline \multirow[b]{3}{*}{$\begin{array}{c}\text { Pre } 1940 \\
1940-44 \\
1945-49 \\
1950-54 \\
1955-59 \\
1960-64 \\
1965-66\end{array}$} & \multicolumn{7}{|c|}{ Industry 1-tyres } & \multicolumn{7}{|c|}{ Remainder of rubber and cablemaking industry } \\
\hline & \multirow{2}{*}{$\begin{array}{c}\begin{array}{c}\text { Population } \\
1967\end{array} \\
2731 \\
934 \\
3402 \\
2848 \\
2683 \\
2596 \\
841\end{array}$} & \multicolumn{2}{|c|}{$\begin{array}{c}\text { All deaths } \\
1968-71\end{array}$} & \multicolumn{2}{|c|}{$\begin{array}{c}\text { Bronchial } \\
\text { carcinoma } \\
1968-71\end{array}$} & \multicolumn{2}{|c|}{$\begin{array}{c}\text { All other } \\
\text { neoplasms } \\
1968-71\end{array}$} & \multirow{2}{*}{$\begin{array}{c}\begin{array}{c}\text { Population } \\
1967\end{array} \\
3245 \\
981 \\
3392 \\
3889 \\
4494 \\
6278 \\
2451\end{array}$} & \multicolumn{2}{|c|}{$\begin{array}{c}\text { All deaths } \\
1968-71\end{array}$} & \multicolumn{2}{|c|}{$\begin{array}{c}\text { Bronchial } \\
\text { carcinoma } \\
1968-71\end{array}$} & \multicolumn{2}{|c|}{$\begin{array}{c}\text { All other } \\
\text { neoplasms } \\
1968-71\end{array}$} \\
\hline & & $\begin{array}{r}205 \\
43 \\
182 \\
127 \\
107 \\
84 \\
35\end{array}$ & $\begin{array}{l}(7 \cdot 5) \\
(4 \cdot 6) \\
(5 \cdot 3) \\
(4 \cdot 5) \\
(4 \cdot 0) \\
(3 \cdot 2) \\
(4 \cdot 1)\end{array}$ & $\begin{array}{r}23 \\
11 \\
31 \\
28 \\
20 \\
13 \\
5\end{array}$ & $\begin{array}{l}(11 \cdot 2) \\
(25 \cdot 6) \\
(17 \cdot 0) \\
(22 \cdot 0) \\
(18 \cdot 7) \\
(15 \cdot 5) \\
(14 \cdot 3)\end{array}$ & $\begin{array}{r}38 \\
7 \\
33 \\
28 \\
10 \\
17 \\
9\end{array}$ & $\begin{array}{r}(18 \cdot 5) \\
(16 \cdot 3) \\
(18 \cdot 1) \\
(22 \cdot 0) \\
(9 \cdot 3) \\
(20 \cdot 2) \\
(25 \cdot 7)\end{array}$ & & $\begin{array}{r}226 \\
57 \\
159 \\
191 \\
216 \\
278 \\
119\end{array}$ & $\begin{array}{l}(7 \cdot 0) \\
(5 \cdot 8) \\
(4 \cdot 7) \\
(4 \cdot 9) \\
(4 \cdot 8) \\
(4 \cdot 4) \\
(4 \cdot 9)\end{array}$ & $\begin{array}{l}23 \\
10 \\
22 \\
28 \\
35 \\
36 \\
16\end{array}$ & $\begin{array}{l}(10 \cdot 2) \\
(17 \cdot 5) \\
(13 \cdot 8) \\
(14 \cdot 7) \\
(16 \cdot 2) \\
(12 \cdot 9) \\
(13 \cdot 4)\end{array}$ & $\begin{array}{l}45 \\
10 \\
26 \\
30 \\
34 \\
57 \\
14\end{array}$ & $\begin{array}{l}(19 \cdot 9) \\
(17 \cdot 5) \\
(16 \cdot 4) \\
(15 \cdot 7) \\
(15 \cdot 7) \\
(20 \cdot 5) \\
(11 \cdot 8)\end{array}$ \\
\hline Total & 16035 & 738 & & 131 & $(16 \cdot 7)$ & 142 & $(18 \cdot 1)$ & 24832 & 1246 & & 170 & $(13 \cdot 6)$ & 216 & $(17 \cdot 3)$ \\
\hline
\end{tabular}


and cablemaking industry according to the year in which individuals entered the industry. The figure illustrates the differences between these two groups with respect to the proportion of deaths attributed to bronchial carcinoma. Although the difference between these proportions is small for those who entered before 1940 or after 1955 , the proportions for those who entered between these dates differ widely. This is consistent with the concept that a lung carcinogen is being used in this sector of the industry and those subjects who were first exposed 15 years or more ago are at most risk because of possible time lags before cases are observed. People who were in the industry before 1940 are, by definition, a survivor group and probably older people.

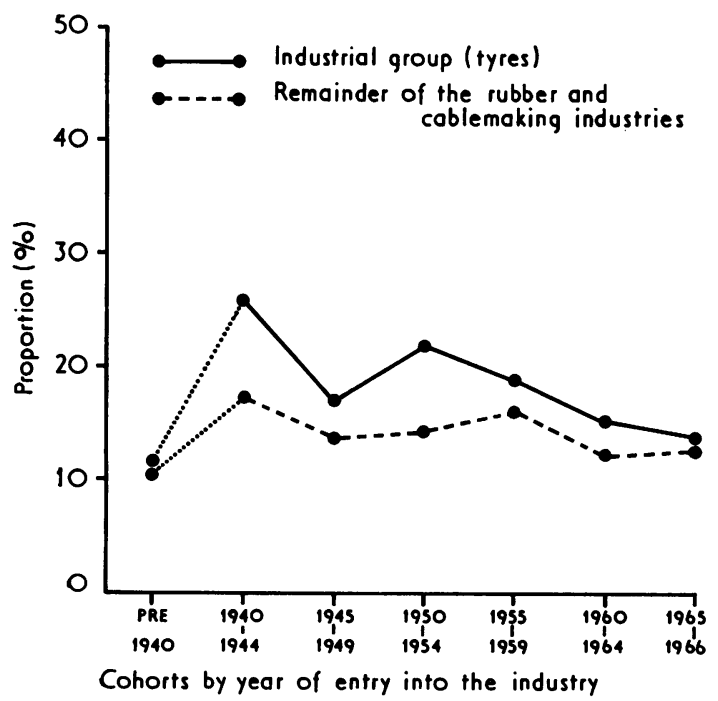

FIGURE Proportion of all observed deaths found to be due to lung cancer according to year in which subjects entered the industry.
The effect of lung carcinogen would consequently be less overt in this group because the deaths attributed to the carcinogen would form a smaller proportion of all deaths.

Table 13 confirms these findings by giving agestandardized expected values for those subjects who entered the industry between 1950 and 1954 . Although the overall SMR for this group is 102, the SMR for carcinoma of the bronchus is 184 and for other neoplasms is 148. These findings emphasize the need for a properly designed cohort study, the cohorts being based both on year of entry into the industry and subsequently on year of departure from the industry.

The results nevertheless indicate that other carcinogens might be in use in the rubber and cablemaking industry. There is an overall significant excess of neoplasm deaths (Tables 2 and 4). The proportions of different cancers observed between 1968 and 1971 are similar for the total industry to those observed nationally in 1969 but there is an increase in numbers. Although this apparent excess occurs throughout the industry, there would also appear to be particular hazards related to the tyre and the belting, hose rubber with asbestos, and flooring industries. These will require further more detailed study.

Since the tyre industry provides approximately $10 \%$ of the total population and an overall cancer risk is found, it is not entirely surprising that a significant excess is demonstrable in this sector. The risk of neoplasms in the tyre industry is found, however, to be approximately $14 \%$ higher than that for the remainder of the rubber and cablemaking industry, and in particular for carcinoma of the bronchus it is found to be approximately $24 \%$ higher (Table 9). In this sector the two job groups which appear to contribute most to this excess are moulding, press, autoclave and pan cureman, and finished goods, stores and packaging despatch. In the former group the excess rate for all neoplasms is

TABLE 13

Mortality Pattern (Deaths Observed 1968-71) by Age at Death for Subjects who entered The TYRE INDUSTRY BETWEEN 1950 AND 1954

(Note comments in the text re 'survivor' population and the incompleteness of this cohort.)

\begin{tabular}{|c|c|c|c|c|c|c|c|c|c|c|c|c|}
\hline \multirow{2}{*}{ Age group } & \multicolumn{3}{|c|}{ Carcinoma of bronchus } & \multicolumn{3}{|c|}{ All other neoplasms } & \multicolumn{3}{|c|}{ Other causes of death } & \multicolumn{3}{|c|}{ All causes of death } \\
\hline & Obs. & Exp. & $S M R$ & Obs. & Exp. & $S M R$ & Obs. & Exp. & $S M R$ & Obs. & Exp. & $S M R$ \\
\hline $\begin{array}{c}35-44 \\
45-54 \\
55-64 \\
65+\end{array}$ & $\begin{array}{r}-8 \\
16 \\
4\end{array}$ & $\begin{array}{l}0.53 \\
3.41 \\
8.63 \\
2.65\end{array}$ & $\begin{array}{l}\overline{235^{1}} \\
185^{1} \\
151\end{array}$ & $\begin{array}{r}4 \\
9 \\
13 \\
2\end{array}$ & $\begin{array}{l}1 \cdot 37 \\
4 \cdot 70 \\
9 \cdot 67 \\
3 \cdot 24\end{array}$ & $\begin{array}{c}292 \\
191 \\
134 \\
62\end{array}$ & $\begin{array}{r}4 \\
19 \\
39 \\
9\end{array}$ & $\begin{array}{r}6 \cdot 36 \\
24 \cdot 28 \\
44 \cdot 54 \\
16 \cdot 85\end{array}$ & $\begin{array}{l}63 \\
78 \\
88 \\
53\end{array}$ & $\begin{array}{r}8 \\
36 \\
68 \\
15\end{array}$ & $\begin{array}{r}8 \cdot 26 \\
30 \cdot 39 \\
62 \cdot 84 \\
22 \cdot 74\end{array}$ & $\begin{array}{r}97 \\
118 \\
108 \\
66\end{array}$ \\
\hline Total & 28 & $15 \cdot 22$ & 184 & 28 & 18.98 & 148 & 17 & $92 \cdot 03$ & 77 & 127 & $124 \cdot 23$ & 102 \\
\hline
\end{tabular}


$42 \%$ and for bronchial carcinoma is $67 \%$ as compared with the rest of the industry excluding the tyre sector. Interpretation of the findings for the latter group is more difficult because of the problem of job selection.

No evidence was found to suggest that this excess might be attributed to an urban effect or to smoking. The death rates for urban and smoking-related causes, in particular for bronchitis and emphysema, in the tyre industry is approximately the same as for the remainder of the rubber and cablemaking industry.

From Table 5 it can be seen that the belting, hose rubber with asbestos, and flooring industry is approximately one quarter the size of the tyre industry. This makes detailed analysis at this relatively early stage in the study much more difficult. There would, however, appear to be approximately $54 \%$ more neoplasms and, in particular, $71 \%$ more bronchial carcinomas than expected by national age-standardized rates. The overall standardized mortality ratio is also high in this sector, making it more difficult to exclude possible urban and smoking effects (Table 8).

An apparent excess in Table 6 in the printing supply industry is not confirmed by more detailed analysis. However, the sample is extremely small (only 315 individuals). Mancuso (1949), in a study of death certificates for the State of Ohio, noted a higher death rate for malignancies of the brain, central nervous system, and respiratory system among employees of the rubber and plastic industries. Guralnick (1963), in a national study of mortality by industry and occupation as recorded on the death certificate, also observed a general excess for all neoplasms and in particular an excess of malignant neoplasms of the respiratory system. The first prospective study to report an excess of malignant neoplasms of the respiratory system was that undertaken by Mancuso, Ciocco, and El-Attar (1968) when they monitored from 1940 to 1964 a cohort who had been in employment in 1938 and 1939 in a particular company manufacturing rubber products. Of a total of 1568 white male employees who were studied in the population, 19 deaths due to carcinoma of the bronchus, trachea, and lung were observed. None of these occurred among the office employees. Of the 19 deaths, 8 occurred in the compounding mill and callender department group. The average annual age at death rate for those 65 and over was found to be 799 , as compared with a rate of 143 for the State of Ohio. A further three deaths due to carcinoma of the lung, all in the 2544 age group, occurred among the curing and tyre building department.

An increase in the prevalence of lung cancer has been observed in a number of occupational groups, including uranium miners (Waggoner et al., 1965) and haematite miners (Boyd, Doll, Faulds, and Leiper, 1970); asbestos workers (Doll, 1955) and workers exposed to asbestos in the insulation industry (Selikoff, Churg, and Hammond, 1964); talc miners and millers (Kleinfeld, Messite, Kooyman, and Zaki, 1967); nickel smelters (Doll, 1958) and workers manufacturing chromates and chrome pigments (Bidstrup and Case, 1956); workers exposed to arsenic in vineyard spraying (Roth, 1958) and sheep-dip production (Merewether, 1944); men employed in coal distillation in the gas industry (Doll, 1952; Doll et al., 1965); and newspaper workers in the printing industry (Moss, Scott, and Atherley, 1972; Greenberg, 1972). Some of these findings may be relevant to the present study. The lung cancer mortality in newspaper workers is reflected in the excess in printing supplies in this study, and emphasizes the need for a separate study of this group to be undertaken. Talc is extensively used in rubber manufacture and the possibility that this material has contributed to lung cancer mortality needs to be investigated. Those sections of the rubber industry which use asbestos may be experiencing an increased mortality attributable to asbestos. The role of aromatic hydrocarbons requires elucidation. Carbon black is a major raw material in the tyre industry, and is also used in the manufacture of printers' ink; it is known to absorb hydrocarbons during production (Falk and Steiner, 1952), but no increase in cancer mortality was found in carbon black workers by Ingalls (1950).

It is possible, therefore, that the findings reported in this paper represent no single cause. There may be synergism with a co-carcinogen, and an effect from smoking similar to the multiplicative effect found in asbestos workers (Selikoff, Hammond, and Churg, 1968; Berry, Newhouse, and Turok, 1972) may also be involved.

It must be emphasized that this study was designed to monitor a group of people who entered the rubber and cablemaking industry after the industry ceased to use known bladder carcinogens. It was thought that there might be related hazards and that these would be detected by this crude method. The population selected is as large as was considered to be practicable and covers the total industry. It is, therefore, a useful population for monitoring the prevalence of disease but not for measuring accurately the excess risks in each subgroup. This is evident from Table 11 where the number of people included in the study from several sectors of the industry is clearly too small for detailed epidemiological study. This is one reason why in particular the excess prevalence in the tyre industry, a large industry, is significant whereas that, for example, in sector 5, a small industry, is not significant when the excess in sector 5 would be estimated to be the greater of the two. 
The population, consisting of those people in the industry as at 1 February 1967, comprises to a great extent a survivor population. Many people, for example, who were employed in the industry before 1954 will have left; also many will have died. Clearly this will affect any estimate of excess. Also included in the population are people who entered the industry as recently as 1965 and early 1966 . In the light of the expected latent periods for several well-known occupational cancer hazards, it is unlikely that these people will have occupationally induced tumours from the industry under study. These people, therefore, have a dilution effect on any measure of excess. Similarly, jobs were recorded as at the first day in the study, and subsequent classifications do not account for job rotation. If excess risks are to be associated with particular jobs and it is desired to measure the extent of these, it is necessary to study cohorts of people according to periods exposed and year of first exposure. Unless there is a tendency for older and less healthy people to be given a particular job, the effect of not accounting for previous jobs is likely to decrease the difference in risks between jobs.

On the other hand, the information collected does not provide an entirely satisfactory estimate of the roles of urban effects and the possible effects of smoking habit. Although the indications are that these are not the primary cause of the excess, they cannot be entirely ruled out, particularly for the belting, hose rubber with asbestos, and flooring industry and the printing supply industry.

The evidence obtained is not conclusive and must be used only as the basis for hypotheses that can be tested in a further study. The evidence suggests that concern should centre on measuring the mortality rates in groups of people who left the industry between 1940 and 1966. These should be accompanied by detailed occupational and smoking histories if accurate measures of the excess are to be obtained.
This study of people who have left the industry should give an indication as to when the incidence of neoplasms increased. Initial attention must be given to specific jobs in the tyre industry and to the belting, hose rubber with asbestos, and flooring industry. The possibility of more than one causative factor being involved must be borne in mind.

A separate study is at present being conducted by the Rubber Manufacturers Association and the Department of Social Medicine at Birmingham University ${ }^{1}$.

We are indebted to many people who have assisted and advised in the running and analysis of this survey. In particular, Dr. G. Hill must receive much of the credit for preparing the survey for computer analysis. The Automatic Data Processing Section of the Department of Employment and Mr. J. Draper, in particular, have provided the necessary computer support.

No survey of this kind can be undertaken without the not inconsiderable assistance of the General Register Office for Scotland and the Office of Population Censuses and Surveys, who have traced almost all the people identified and subsequently notified causes of death. Dr. J. W. Donovan and Dr. J. A. Waterhouse have made several extremely useful comments on statistical aspects of early drafts of this report.

We are also grateful to Dr. T. A. Lloyd Davies, Chief Medical Adviser, Department of Employment, for permission to publish these results.

${ }^{1}$ Reports of a possible lung cancer hazard in the rubber industry were first presented to the Department of Employment Industrial Health Advisory Committee in the autumn of 1972. These were based upon prima facie evidence of such a hazard arising from a Departmental study of the incidence of occupational bladder cancer in the rubber industry, but they did not support any final conclusion about the existence of a lung cancer hazard. Manufacturers concerned therefore agreed tosupport and finance a full epidemiological investigation which is now beins carried out in collaboration with the Department of Social Medicine at Birmingham University. It is hoped that the investigation may be completed by the end of 1974, and an undertaking has been given that the detailed findings and conclusions will then be offered for publication.-EDITOR.

\section{References}

Berry, G., Newhouse, M. L., and Turok, M. (1972). Combined effect of asbestos exposure and smoking on mortality from lung cancer in factory workers. Lancet, 2, 476-479.

Bidstrup, P. L. and Case, R. A. M. (1956). Carcinoma of the lung in workmen in the bichromates-producing industry in Great Britain. British Journal of Industrial Medicine, 13, 260-264.

Boyd, J. T., Doll, R., Faulds, J. S., and Leiper, J. (1970). Cancer of the lung in iron-ore (haematite) miners. British Journal of Industrial Medicine, 27, 97-105.

Case, R. A. M. and Hosker, M. E. (1954). Tumour of the urinary bladder as an occupational disease in the rubber industry in England and Wales. British Journal of Preventive and Social Medicine, 8, 39-50.

McDonald, D. B., and Pearson, J. T. (1954). Tumours of the urinary bladder in workmen engaged in the manufacture and use of certain dyestuff intermediates in the British chemical industry. Part I. The role of aniline, benzidine, alpha-naphthylamine and betanaphthylamine. British Journal of Industrial Medicine, 11, 75-104.

Davies, Joan M. (1965). Bladder tumours in the electriccable industry. Lancet, 2, 143-146.

Doll, R. (1952). The causes of death among gas-workers with special reference to cancer of the lung. British Journal of Industrial Medicine, 9, 180-185.

(1955). Mortality from lung cancer in asbestos workers. British Journal of Industrial Medicine, 12, 81-86.

(1958). Cancer of the lung and nose in nickel workers. British Journal of Industrial Medicine, 15, 217-223.

, Fisher, R. E. W., Gammon, E. J., Gunn, W., Hughes, G. O., Tyrer, F. H., and Wilson, W. (1965). Mortality of gasworkers with special reference to cancers of the lung and bladder, chronic bronchitis, and pneumoconiosis. British Journal of Industrial Medicine, 22, 1-12.

Falk, H. L. and Steiner, P. E. (1952). The identification of 
aromatic polycyclic hydrocarbons in carbon blacks. Cancer Research, 12, 30-39.

Greenberg, M. (1972). A proportional mortality study of a group of newspaper workers. British Journal of Industrial Medicine, 29, 15-20.

Guralnick (1963). U.S. Department of Health, Education, and Welfare, Mortality in 1950 by Occupation and Industry, Vital Statistics-Special Reports, 53: 1-5, June 1961-September 1963.

H.M. Chief Inspector of Factories (1968). Annual Report 1967, pp. 81-82. H.M.S.O., London.

Howe, G. M. (1963). National Atlas of Disease Mortality in the United Kingdom. Nelson, London.

Hueper, W. C., Wiley, F. H., and Wolfe, H. D. (1938). Experimental production of bladder tumors in dogs by administration of beta-naphthylamine. Journal of Industrial Hygiene and Toxicology, 20, 46-84.

Ingalls, T. H. (1950). Incidence of cancer in the carbon black industry. Archives of Industrial Hygiene and Occupational Medicine, 1, 662-676.

International Classification of Diseases (1967). 8th edition. W.H.O., Geneva.

Kleinfeld, M., Messite, J., Kooyman, O., and Zaki, M. H. (1967). Mortality among talc miners and millers in New York State. Archives of Environmental Health, 14, 663667.

Lancet (1964). Cancer research (annotation). Lancet, 2, 25.

- (1965a). Industrial cancer of the bladder (report of inquest). Lancet, 1, 328.

- (1965b). Occupational bladder tumours and the control of carcinogens (leading article). Lancet, 1, 306-307.

- (1965c). Bladder cancer and the rubber industry (annotation). Lancet, 1, 1106.

Lloyd Davies, T. A. (1971). In Annual Report of H.M. Chief Inspector of Factories, 1970, pp. 52-56. H.M.S.O., London.

Mancuso, T. F. (1949). Occupational cancer survey in Ohio. Proceedings of the Public Health Cancer Association of America, pp. 56-70.

- Ciocco, A., and El-Attar, A. A. (1968). An epidemiological approach to the rubber industry-A study based on departmental experience. Journal of Occupational Medicine, 10, 213-232.

Merewether, E. R. A. (1944). In Annual Report of the Chief
Inspector of Factories and Workshops, 1943, p. 45. H.M.S.O., London.

Moss, E., Scott, T. S., and Atherley, G. R. C. (1972). Mortality of newspaper workers from lung cancer and bronchitis 1952-66. British Journal of Industrial Medicine, 29, 1-14.

Parkes, G. (1964). Cancer research (letter to the editor). Lancet, 2, 254-255.

Parkes, H. G. (1969). Epidemiology and etiology of human bladder cancer; occupational bladder cancer in the British rubber industry. Journal of the National Cancer Institute, 43, 249-252.

Pearson, E. S., and Hartley, H. O. (1962). Biometrika Tables for Statisticians, vol. 1, 2nd ed. Cambridge University Press, London.

Peto, R. (1973). Experimental survival curves for intervalcensored data. Applied Statistics, 22, 86-91.

Registrar General (1967-70). Statistical Reviews of England and Wales, Part 1, Tables, Medical. H.M.S.O., London.

- (1967). Decennial Supplement, England and Wales, 1961, Area Mortality. H.M.S.O., London.

Rehn, L. (1895). Blasengeschwülste bei Fuchsin-Arbeitern. Archiv für klinische Chirurgie, 50, 588-600.

Roth, F. (1958). Uber den Bronchialkrebs arsengeschädigter Winzer. Virchows Archiv, 331, 119-137.

Royal College of Physicians (1971). Smoking and Health Now. Pitman Medical and Scientific Publishing, London.

Selikoff, I. J., Churg, J., and Hammond, E. C. (1964). Asbestos exposure and neoplasia. Journal of the American Medical Association, 188, 22-26.

- Hammond, E. C., and Churg, J. (1968). Asbestos exposure, smoking and neoplasia. Journal of the American Medical Association, 204, 106-112.

Veys, C. A. (1969). Two epidemiological inquiries into the incidence of bladder tumors in industrial workers. Journal of the National Cancer Institute, 43, 219-226.

Waggoner, J. K., Archer, V. E., Lundin, P. E. Jr., Holaday, D. A. and Lloyd, J. W. (1965). Radiation as the cause of lung cancer among uranium miners. New England Journal of Medicine, 273, 181-187.

Received for publication 22 May, 1973

Accepted for publication 17 August, 1973 